\title{
CORPORATE COMMUNICATIONS IN CHINA: A PRELIMINARY STUDY
}

\author{
$12^{\text {th }}$ ICIG Meeting \\ Vila Bled, 29 ${ }^{\text {th }}$ September 2009
}

\author{
Ying Fan \\ Brunel Business School \\ Brunel University \\ Uxbridge UB8 3PH \\ England \\ ying.fan@brunel.ac.uk
}

\begin{abstract}
Corporate communications on the internet has played an increasingly important role in China, given the country now has the largest number of internet users in the world. The paper reports a survey of 10 Chinese companies. A total of 20 corporate websites were examined using content analysis. Key topics relating to corporate communications were identified and discussed.
\end{abstract}

\section{Keywords}

Corporate Communications, Branding, Corporate Reputation, Social Responsibility, Corporate Website, China 


\section{Corporate Communications in China: A Preliminary Study}

\section{Introduction}

Although the world's first print advertisement appeared in China more than a thousand years ago featuring a brand called Liu's Needle Workshop, branding is a relatively new concept to both Chinese companies and consumers. Since the transition to a market economy began in 1978, the development of marketing and branding in China can be roughly divided into four stages (Fan, 2006). Table 1 summarises the major changes taking place over the last 30 years.

(Insert Table 1 about here)

Chinese companies think branding is important, and they want to understand what a brand is; but they don't have any experience" (Business Week, 2004). The majority of brands in China today remain little more than a well-known name, lacking the key attribute of a good brand. Facing an ever changing environment, Chinese business leaders have begun to take branding more seriously, but their understanding of the concept remains vague and superficial. One problem is the confusion between corporate and product branding. In a typical advertising campaign the message would speak of the firm's history, its production capability, its technological competence, its position as a market leader, and the number of prizes it has won. What is promoted is a corporate name, rather than the brand value of the offer to the buyer. Without product branding, it is very difficult to differentiate competing offerings, and there is no emotional incentive for the consumer to buy. As a result, there is only sales competition, which often leads to vicious price wars (Fan, 2006). The confusion is caused partly by the difference in language as there is no direct translation for the term of branding in Chinese. It can be rendered only as a noun 品牌 (the same as brand), not as a verb. Corporate branding, on the other hand, can only be translated as 公司品牌 (company brand). Extensive search has been carried out using baidu.com -the largest search engine in Chinese, no publication or reference was found for corporate branding.

Corporate Communications refers to the set of activities involved in managing and orchestrating all internal and external communications aimed at creating favourable starting points with stakeholders on which the company depends (Riel and Fombrun, 2007). Corporate communications is the strategic management process by which an organisation communicates with its various audiences to the mutual benefits of both and with a clear aim to enhance its corporate reputation. Corporate communication consists of the dissemination of information by using a variety of channels, the internet being one of the key strategic functional areas to the corporate communications professionals (Goodman, 2006). 
China now has 338 million internet users out of a total population of 1.3 billion, by far the largest in the world (CNNIC, 2009). 95 percent users have broadband connections. To put this figure in context: India has 81 million users (http://www.startupdunia.com), a penetration rate of 7.2 percent compared to China's 26 percent. In a country where most other types of media are still under the government's firm grip, the internet has become a prevalent and relatively open channel of communication. Communications on the internet in the form of corporate websites has played an increasingly important role in China. The purpose of this short paper is to report a preliminary study of corporate communications in China. Communications on the internet in the form of corporate websites has played an increasingly important role in China,

\section{The Study}

A survey of 10 companies has been conducted. The sample is based on the list of Top 10 Most Respected Companies in China published by the Wall Street Journal Asia (2008). For each company, two websites (in Chinese and English) were found. A total of 20 websites are examined using content analysis. Table 2 presents the background details of the sample. In the sample, with the exception of SAIC whose ownership is not specified, all other companies are publicly owned, for example, baidu is listed in Nasdaq. In the case of Haier and BaoSteel, the state is the largest shareholder. Six companies are the market leaders in their own sector.

(Insert Table 2 about here)

\section{The Findings}

There is no distinction between corporate website and consumer website; as a result, each website performs a multiple function and contains an enormous amount of information, from corporate history to product specification. A few of them are very cluttered, for example, the CMB site. Seven topical areas relating to corporate communications have been identified, namely, company profiles, history, organisation and management team, corporate culture, company news or press coverage, investor relations, social responsibility. (Insert Table 3 about here)

\section{Corporate branding/ corporate culture}

While the primary purpose of product branding is to aid sales and profitability, the primary purpose of corporate branding is to embody the value system of the company and to help promote and enhance corporate reputation. Given the confusion between corporate and product branding mentioned afore, there is little information on corporate branding. Vanke is the only company in the sample that provides a detailed description of its corporate identity, its meaning and links with the company's core values.

The Vanke's brand logo and its interpretation (the author's translation) 


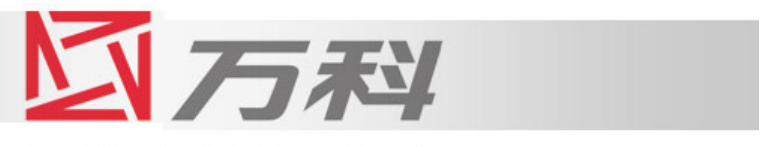

\section{让建 筑赞美生命}

1. The four rotating Vs represent the window pattern in a traditional house, symbolising the company's core business is the development of residential property.

2. Each $\vee$ faces a different direction, symbolising people having different needs in their ideal home.

3. Four Vs are perfectly aligned, indicating the company strives for new building modes that improve the quality while reducing waste and environment pollution.

4. Four Vs echo and relay each other, symbolising the company takes social responsibility and adheres to sustainability

5. Four Vs are bright and lively, symbolising our employees are joyful, healthy and confident.

(The slogan below the logo reads: Let buildings praise life.)

Seven companies have a section on corporate culture. Two examples are given below:

Baosteel's culture with "spirit of strictness and demanding, road of study and innovation, striving for first-class target" as the main thread and "good faith and synergy" as the basic value is the most valuable spiritual wealth of Baosteel and is the prime driver of Baosteel's new round of development.

Core values of SAIC are listed as:

- Satisfaction from customers

- Advantage through innovation

- Internationalisation in operating

- Concentration on people

It is, however, unclear how these core values are linked to their corporate brand equity, and how they are communicated to the general public.

\section{Top management /CEO}

A corporate leader has a significant role in corporate communications. In many cases, they are widely regarded as the face of the organisation (Dolphin and Fan, 1999), or they are the company. Nine companies provide information about its top management team or organisation structure. In addition, Haier and Baidu offered a detailed account about their CEO. This is a clear departure from a traditional culture that would promote more collective efforts than individuals, but it does make sense as both CEOs are a high profile business leader and well known public figure. In this case, it is the same thing to promote the CEO as to promote the company.

\section{Corporate reputation}


Corporate reputation can be defined in terms of a number of attributes that form a buyer's perception as to whether a company is well known, good or bad, reliable, trustworthy, reputable and believable (Levitt, 1965). Corporate reputation is concerned with how people feel about a company based on whatever information (or misinformation) they have on, company activities, workplace, past performance and future prospects (Fombrun, 2000). Many Chinese business leaders now consider corporate reputation to be essential to the development of their companies. This was clearly reflected in a survey by Hill \& Knowlton (2004). Among the 122 Chinese business leaders polled, 89 percent thought that corporate reputation has tangible business value and should be the concern of senior management. To the mind of a Chinese manager, corporate reputation derives from two important sources: formally from official recognition and informally from guanxi recommendations. A firm's status or reputation derives not from the recognition in the marketplace, but from the top that is, via official recognition (Fan, 2007). A case in point is Wuliangye. In its website, there is a slide show of visits by top party and government leaders present and past. This is a powerful promotion technique used by many Chinese organisations. Pictures of shaking hands with high-status officials or attending official functions virtually guarantee a headline in the local media, which will prove more effective than any amount of paid-for advertising in convincing the audience of the organisation's status, prestige and official recognition. Visitors to any Chinese headquarter office will be greeted by prominently placed photographs of such crucial events, alongside reproductions of the apothegms of leaders, calligraphic inscriptions, certificates, silk award banners, and the like. However, this began to change, though very slowly. In recent years, companies have realised the importance of obtaining recognition from other sources, particularly from the marketplace. In Haier's website, the company provides a long list of more than 100 awards and market ranking results.

\section{Corporate social responsibility (CSR)}

CSR is related to the social contract between business and society in which it operates, while business ethics requires organisations to behave in accordance with carefully thought-out rules or moral philosophy (Robin and Reidenbach, 1987). Of the ten companies surveyed seven have a section on CSR subject, with five further offering a report for download. These reports, although entitled differently as "sustainability report", "social responsibility report" or "environment report", contain largely similar contents that cover almost all aspects: from charitable activities to social contributions, from stakeholder relations to environment protection. It is beyond the scope of this paper to go into details of each report, however, it is interesting to note: $\mathrm{CMB}$ reports gives detailed account of every donation it has made. ZTE is the only one to acknowledge the deficiency in performing social responsibility and the need for self improvement.

The first CSR report was published by State Grid Corp China in 2004. Five years on, this remains a rare activity performed by a tiny minority of Chinese companies. Not surprisingly, 
the publication of such reports by some of China's top companies was headline news. On $26^{\text {th }}$ May 2009, 19 companies published their reports in an official ceremony organised by 10 government ministries and agencies. The event was held in the Great People's Hall. Moutai was one of them but its report is not available on its website. In the keynote speech, the minister of industry and information set out the four priorities for Chinese firms in performing social responsibilities: stabilise employment, ensure safety in production, maintain integrity and trust, save resources and protect environment, which reflect the unique challenges face Chinese business leaders.

\section{Discussion and Conclusion}

Branding has become a hugely popular topic among Chinese academics and practitioners over the last few years, as evidenced by the growing number of books, articles and discussions on the internet, as well as numerous training courses offered by business schools. However, branding development in China is still at an early stage and this is characterised by the following problems. Firstly, for the majority Chinese companies, they want to develop branding but are hampered by the lack of a basic understanding. As a consequence, they have no choice but continue to do OEM, i.e. remaining an unknown producer for foreign brands. Secondly, a considerable number of Chinese companies have quality products and good marketing ideas. What they lack is the right expertise and experience to bring them into practice. Their branding strategy often fell apart in the implementation stage. Nationwide, there is a severe shortage of qualified branding professionals in every sector. Thirdly, a small number of Chinese companies, such as Haier and Lenovo, have already made rapid strides in globalising their business operations (Fan, $2006,2008)$. One of the main obstacles they face is how to overcome the negative effect of "Made-in-China" to build a strong brand image in the international marketplace. Two different approaches have been adopted in developing global brands. The organic growth approach is typified by Haier; the short-cut approach is used by Lenovo and SAIC that tried to accelerate internationalisation via acquisition of foreign brands. It is still too early to evaluate which approach works better.

Clearly, there is an urgent need for Chinese companies to develop new competence in branding. The key question is: Can western theories help solve China's branding problems? Branding, like other marketing subjects or theories, has originated in the western developed countries by large multinational companies. With their operations in China, they have brought in with them these "new" thinking and practices. Chinese companies and business men, on the other hand, had been practising marketing in their own way for thousands of years until recently; they have now found themselves exposed to these advanced or "superior" foreign concepts and techniques. Previously studies have questioned the applicability and transferability of marketing knowhow from developed countries being applied wholesalely to developing countries (Cavusigil and Yavas, 1984; Fan, 1998; Newell, 1999). Siu and Kirby (1995) provide empirical evidence that marketing principles generated 
from the West are not always suitable or applicable in some specific socio-cultural contexts, emphasising the need to adapt marketing knowledge to suit local needs.

Corporate branding and corporate communications is the subject particularly affected by a country's political economic systems and social cum cultural environment. The complexity of the subject itself and difficulty in conducting research in China make it an extremely interesting area for research. This survey presents a snapshot of how corporate communications has been practised on the internet by some of China's most prominent and respected companies. As a preliminary study, one obvious limitation is the use of a small convenience sample. Future research could employ a larger sample and examine communications both in conventional media and on the internet. Comparisons between Chinese firms and multinational companies operating in China could produce more insights.

\section{References}

Business Week (2004), "China goes shopping", Business Week, available at: www.businessweek.com/magazine/content/04_51/b3913041_mx011.htm

Cavusgil, S. T. and Yavas, U. (1984). "Transfer of management knowhow to developing countries: An empirical Investigation", Journal of Business Research, 12, pp. 35-50.

CNNIC, (2009), the $24^{\text {th }}$ Statistical Report on Internet Development in China http://www.cnnic.cn/html/Dir/2009/07/28/5644.htm

Dolphin, R. R. and Fan, Y. (2000) "Is corporate communications a strategic function?" Management Decision, 38:2, 99-106

Fan, Y. (2008), "Country of origin, branding strategy and internationalisation: the case of Chinese piano companies", Journal of Chinese Economic and Business Studies, 6:3, 303-319

Fan, Y. (2007), "Guanxi, government and Corporate reputation in China: Lessons for international companies", Marketing Intelligence and Planning, 25:5, 499-510

Fan, Y. (2006), "The globalisation of Chinese brands", Marketing Intelligence \&Planning, 24:4, 365-379

Fan, Y. (1998), "The transfer of western management to China", Management Learning, 29:2, 201-221.

Fombrun, C. (2000), "The value to be found in corporate reputation", Financial Times, 4 December

Goodman, M. B. (2006), "Corporate communication practice and pedagogy at the dawn of the new millennium", Corporate Communication, 11:3, 196-213.

Hill \& Knowlton (2004), "2004 Corporate reputation watch (China): summary of findings", available at: www.corporatereputationwatch.com

Levitt, T. (1965), Industrial Purchasing Behaviour: A Study of Communication Effects, Harvard Business School, Boston, MA.

Newell, S. (1999), "The transfer of management knowledge to China - Building learning communities rather than translating western textbook?", Education + Training. 41:6/7, 286293

Riel, C.B.M. van \& Fombrun, C. (2007), Essentials of Corporate Communication, Abingdon: Routledge 
Robin, D.P. and Reidenbach, R.E. (1987), "Social responsibility, ethics, and marketing strategy: closing the gap between concept and application", Journal of Marketing, Vol. 51, January, pp. 44-58.

Siu, W. S. and Kirby, D. A. (1995), "Marketing in Chinese small business: Tentative theory", Journal of Enterprising Culture 3:3, 309-342.

The Wall Street Journal Asia, (2008), "the 200 Most respected companies in Asia", $25^{\text {th }}$ July

Websites surveyed

http://home.baidu.com/

http://www.baosteel.com/plc e/index.asp

http://english.cmbchina.com/

http://www.haier.cn/

http://www.lenovo.com/

http://www.moutaichina.com/index.asp

http://www.saicgroup.com/Chinese/index.shtml

http://www.vanke.com/main/default.aspx

http://www.wuliangye.com.cn/pages/

http://www.zte.com.cn/cn/ 
Table 1 The development of branding in China

\begin{tabular}{|l|l|l|l|l|}
\hline & $1978-1991$ & $1992-2001$ & $2002-2007$ & $2008-$ \\
\hline Major event & Open door policy & Reform deepened & WTO membership & Beijing Olympics \\
\hline Economy & $\begin{array}{l}\text { State ownership over } \\
80 \%, \text { severe shortage }\end{array}$ & $\begin{array}{l}\text { Over capacity, intense } \\
\text { competition }\end{array}$ & $\begin{array}{l}\text { State ownership less } \\
\text { than 20\%, part of global } \\
\text { economy }\end{array}$ & $\begin{array}{l}\text { Impact of global } \\
\text { economic crises }\end{array}$ \\
\hline $\begin{array}{l}\text { Marketing } \\
\text { focus }\end{array}$ & Production & Selling \&advertising & Advertising /branding & Branding, Innovation \\
\hline
\end{tabular}

Table 2 Background of the top 10 most respected companies in China (WSJA, 2008)

\begin{tabular}{|l|c|c|c|c|c|c|}
\hline Rank & Established in & Main sector & $\begin{array}{l}\text { Market } \\
\text { position }\end{array}$ & Ownership & Employee & $\begin{array}{l}\text { Turnover (bn RMB) } \\
\text { in 2008 }\end{array}$ \\
\hline 1.Haier & 1984 & Home appliance & No.1 & State/Public & 50,000 & 119 \\
\hline 2.CMB & 1987 & Banking & 6 & Public & 37,000 & 55.6 \\
\hline 3. Lenovo & 1984 & computing & 1 & Public & 23,000 & (US\$16.8bn) \\
\hline 4.Vanke & 1984 & Real estate & 1 & Public & 13,000 & 40.5 \\
\hline 5.Baidu & 2000 & Internet search & 1 & Public & 7,000 & $1.74(2007)$ \\
\hline 6.BaoSteel & 1978 & Steel & 1 & State/Public & 32,000 & 201 \\
\hline 7. ZTE & 1985 & Telecom & 2 & Public & 50,000 & 30.3 \\
\hline 8.Wuliangye & 1959 & Beverage & 1 & Public & 30,000 & 30.1 \\
\hline 9.SAIC & 1955 & Automobile & 3 & State? & 82,000 & 163.8 \\
\hline 10.Moutai & 1997 & Beverage & 2 & Public & n.a. & 9.1 \\
\hline
\end{tabular}

Source: compiled from company website, baike.baidu.com

Table 3 Topical contents in the corporate website

\begin{tabular}{|c|c|c|c|c|c|c|c|c|}
\hline & Profile & History & $\begin{array}{l}\text { Organisation } \\
\text { /CEO }\end{array}$ & $\begin{array}{l}\text { Corporate } \\
\text { culture }\end{array}$ & $\begin{array}{l}\text { News/ } \\
\text { press }\end{array}$ & $\begin{array}{l}\text { Investor } \\
\text { relations }\end{array}$ & $\begin{array}{l}\text { Social } \\
\text { responsibility }\end{array}$ & $\begin{array}{l}\text { Other } \\
\text { information }\end{array}$ \\
\hline Haier & $x$ & $x$ & $x$ & $x$ & $x$ & $x$ & $\begin{array}{l}\mathrm{X} \\
\text { Environment } \\
\text { report }\end{array}$ & $\begin{array}{l}\text { Global } \\
\text { presence }\end{array}$ \\
\hline $\mathrm{CMB}$ & $x$ & $x$ & $x$ & & $x$ & $x$ & CSR Report & $\begin{array}{l}\text { Corporate } \\
\text { governance }\end{array}$ \\
\hline Lenovo & $x$ & $x$ & $x$ & & $x$ & $x$ & $\begin{array}{l}\text { Sustainability } \\
\text { report }\end{array}$ & $\begin{array}{l}\text { Global } \\
\text { presence }\end{array}$ \\
\hline Vanke & $x$ & $x$ & $x$ & $x$ & & $x$ & & $\begin{array}{l}\mathrm{Cl} \text {, branding } \\
\text { employee } \\
\text { handbook }\end{array}$ \\
\hline Baidu & $x$ & $x$ & $x$ & $x$ & $x$ & $x$ & & $\begin{array}{l}\text { Professional } \\
\text { moral code }\end{array}$ \\
\hline BaoSteel & $x$ & $x$ & $x$ & $x$ & $x$ & $x$ & $\begin{array}{l}\text { Sustainability } \\
\text { report }\end{array}$ & Stock price \\
\hline ZTE & $x$ & $x$ & & & $x$ & $x$ & CSR Report & $\begin{array}{l}\text { Publication of } \\
\text { three } \\
\text { journals }\end{array}$ \\
\hline Wuliangye & $x$ & $x$ & $x$ & $x$ & $x$ & $x$ & & $\begin{array}{l}\text { Visits of party } \\
\text { leaders, } \\
\text { awards }\end{array}$ \\
\hline SAIC & $x$ & $x$ & $x$ & $x$ & $x$ & & $x$ & Annual report \\
\hline Moutai & $x$ & $x$ & $x$ & $x$ & $x$ & $x$ & $x$ & $\begin{array}{l}\text { Counterfeit } \\
\text { check }\end{array}$ \\
\hline
\end{tabular}

